\title{
Should Workers Care about Firm Size? ${ }^{1}$
}

\author{
Ana Ferrer \\ Stéphanie Lluis \\ University of British Columbia ${ }^{2} \quad$ University of Minnesota ${ }^{3}$
}

January 2004

${ }^{1}$ We thank seminar participants at the university of British Columbia and the university of Minnesota for valuable comments on earlier versions of this paper.

${ }^{2}$ Department of Economics, 997-1873 East Mall, Vancouver, BC V6T 1Z1, Canada. Tel: (604) 822 8606, e-mail: aferrer@interchange.ubc.ca

${ }^{3}$ Industrial Relations Center, 321 19th Avenue South, Minneapolis, MN 55455, USA. Tel: (612) 624 4171, e-mail: slluis@csom.umn.edu 


\begin{abstract}
The question of wage differentials by firm size has been studied for several decades with no commonly accepted explanations for why large firms pay more. In this paper, we reexamine the relationship between firm-size and wage outcomes by estimating the returns to unmeasured ability between large and small firms. Our empirical methodology, based on non linear instrumental variable estimations, allows us to directly estimate the returns to unmeasured ability by firm size and therefore to test the two main theories of wage determination proposed to explain the relationship between firm size and wages, namely ability sorting and job screening. We use data from the Survey of Labour and Income Dynamics (SLID) which provides longitudinal information on workers and firms characteristics including establishment and firm size. We find significant differences in the returns to unmeasured ability across firm size. In particular, we find that the returns to unmeasured ability seem to follow a non linear pattern. The returns to unmeasured ability are significantly higher in medium size (above 500 but below 1000 workers) firms relative to small firms. However, the returns to unmeasured ability are not significantly greater in large firms relative to medium or small firms. Overall, it seems that ability sorting dominates for moves from small to medium size firms in that ability is more productive and therefore more rewarded in the latter than the former. On the other hand, when firms become "too large", the monitoring costs hypothesis seems to dominate in that ability is not more rewarded than in smaller firms.
\end{abstract}

JEL CODES: J31 J33 J41 J62

Key words: Firm Size, Comparative Advantage, Self-selection, Job Screening, Ability Sorting 


\section{Introduction}

The existence of firm-size wage differentials, the observation that firms of different sizes pay different wages for observationally equivalent workers, is a widely documented fact in the empirical literature on wage determination. These studies generally find that none of the explanatory variables used in the wage equation can account for the existence of a size-wage gap. ${ }^{1}$ As a result, the literature has concluded that the explanation resides in unmeasured factors in the error term. This term might capture intrinsic differences in individual ability affecting workers decisions to join a large or a small firm. It may also represent differences between large and small firms' decisions to reward the various aspects of the workers' skills. Two plausible theories of wage determination offer suggestions as to what this unmeasured factor might be. The first one is ability sorting, in which high ability workers have a comparative advantage in larger firms, and the second is job screening, according to which greater monitoring costs in larger firms implies lower reward associated with ability or any individual traits, difficult to measure on the job. So far, the literature has not been able to test any of these theories as the empirical methods used either did not include an unmeasured ability term (simple OLS) or attempted to difference it out using fixed-effects.

In this paper, we reexamine the relationship between firm-size and wage outcomes by emphasizing the role of unmeasured (to the econometrician) ability and the non random allocation of workers into firms of different sizes. We apply GMM techniques to longitudinal data on wages and benefits and employer size to estimate and test for differences in the returns to unmeasured ability between large and small firms. The method based on non linear instru-

\footnotetext{
${ }^{1}$ Even in the most recent empirical literature using richer data on human capital aspects such as the presence of training opportunities (Hu (2003)), on-the-job-search (Winter-Ebmer and Zweimuller (1999)) or better information on the employer side using matched employer-employee data (Troske (1999)), the size-wage premium cannot be fully explained by any of the factors analyzed.
} 
mental variables permits a direct estimation of the returns to unmeasured aspects of skills. This will allow us to test the two main theories of wage determination proposed to explain the relationship between firm size and wages, namely ability sorting and job screening.

The estimated size-wage premium is about $15 \%$ in the United States and $10 \%$ in Canada. Empirical studies investigating the source of this wage differential have analyzed the explanatory power of various factors related to worker and firm characteristics such as education, unionization and industry type. ${ }^{2}$ These studies have been limited in two ways. First, they do not allow for the possibility that human capital attributes may not be equally valued in large and small firms. By doing so, they restrict the effect of firm size on wages to being only a shift parameter. Second, the use of fixed-effect estimations allows one to eliminate the bias caused by the ability term (assuming it is time invariant and equally rewarded in large and small firms) to estimate the effects of other parameters. On the other hand, it does not allow an estimation of ability effects. Moreover, if large and small firms have different wage policies concerning their treatment of measured and unmeasured skills, then the fixed-effect method does not eliminate the effect of unmeasured ability on wage outcomes.

This paper addresses the particular role of ability in the wage policy decisions of large and small firms in a framework of non random assignment of workers into firms of different sizes. On the employer side, firms of different size have distinct wage policies regarding the evaluation of the various dimensions of human capital. On the workers side, individuals with a particular set of skills have a comparative advantage in companies of a given size. In this framework, both measurable (education and experience) and unmeasurable (initiative, ambition, loyalty) human capital attributes are differently rewarded across firms of different sizes. Therefore, individuals will self-select into large and small firms according to such policies and their own endowment of measured and unmeasured skills.

\footnotetext{
${ }^{2}$ See Oi and Idson (1999) for a review of the literature on firm size and wages in the US.
} 
The two leading theories of wage determination used to explain the relationship between firm size and wage outcomes, ability sorting and job screening, can be tested in a wage equation framework because each theory provides different predictions in terms of the returns to unmeasured skills or ability. According to the ability sorting argument, large firms attract high ability workers because they need better workers as the execution of the different production processes in large firms is more complex than in small firms. ${ }^{3}$ In addition, large firms have more ways to attract better workers than small firms by providing promotion opportunities, training and career development. ${ }^{4}$ As a result, returns to unmeasured skills or ability should be greater in large firms than in small ones. In the job screening hypothesis, larger firms have higher monitoring costs than small firms which leads large firms to more highly value directly observed skills (like education and experience) and value less unobservable skills compared to small firms. ${ }^{5}$ As a result, returns to ability should be smaller in large than in small firms, a prediction opposite to the ability or productivity hypothesis.

The importance of worker self-selection in the analysis of firm size on wages has been previously analyzed by Idson and Feaster (1990) using cross-sectional data from the 1979 May

\footnotetext{
${ }^{3}$ See Oi (1983) and Oi and Idson (1999) for a theoretical and empirical analysis of the productivity explanation of the size-wage gap.

${ }^{4}$ See Gibbons (1998) for a review of the empirical literature on wage dynamics within organizations and the role of ability in career development (fast-tracks). More recently, Agell (2003) conducts an empirical analysis of the differences in compensation policies between small and large U.S. firms. The author finds evidence that career ladders and the use of performance pay increases with firm size.

${ }^{5}$ See Garen (1985) for a theoretical model and an empirical test supporting this prediction. Barron, Black and Loewenstein (1987) present evidence of a related implication of the monitoring costs hypothesis. They find that large employers screen applicants more extensively compared to small employers and provide higher starting wages. More recently, $\mathrm{Hu}$ (2003) uses cross-sectional data from the Benefits supplement of the CPS to show that large employers hire younger workers than small employers and that the size-wage premium for newly hired workers disappears for workers older than 35. Both empirical studies are consistent with the idea that large firms use pre-hiring screening practices to reduce monitoring costs associated with on-the-job screening.
} 
CPS and Lluis (2003) comparing the size-wage structure in the U.S. and Canada with data from the U.S. CPS and the Canadian LFS for the year 1998. The latter author finds a similar wage structure in both countries as well as evidence of non random selection of workers into firms of different sizes. In both of these studies, the method used to characterize non random selection is the Heckman two-step method. Although this method provides evidence of the presence of workers non random selection, it does not provide any quantitative information on the importance of unmeasured ability in the selectivity mechanism. Moreover, the selection model is one-sided in that it characterizes workers' decisions to join a firm but remains silent on firms' selection decisions. However, the overall effect of firm size on wages depends on both which types of workers tend to choose to work in a large or a small firm as well as the effect of firm size on the wages of different types of workers.

The method we use in the paper relies on a panel data estimator estimated using GMM techniques. It is appropriate for the analysis of multi-sector models of wage determination in which the time-invariant component of the error term is differentially rewarded and selection comes from both sides of the market. ${ }^{6}$ This type of analysis requires panel data where a sufficiently large number of individuals can be observed for at least three time periods. Our analysis is applied to longitudinal data from the Canadian Survey of Labour and Income Dynamics (SLID) conducted over the period 1993 to 1998. This household survey provides an extensive set of individual, job and firm characteristics and its panel aspect constitutes a unique source of information for an analysis of the dynamic interactions of workers, firm size, and wages. Previous studies analyzing the size-wage gap in Canada and the U.S. have used cross-sectional data or only 2-year panels. ${ }^{7}$ More recently, Troske (1999) analyzes the

\footnotetext{
${ }^{6}$ Lemieux (1998) applies the method to analyze the effects of union sector choice on wages. Gibbons, Katz, Lemieux and Parent (2002) use this method to analyze inter-occupation and inter-industry wage differentials. Lluis (2002) uses the method to analyze the wage dynamics associated with worker choices of job ranks within a company.

${ }^{7}$ See Oi and Idson (1999) for a review of the U.S. studies and Morissette (1993) for a study of the Canadian
} 
question using U.S. matched employer-employee data but reaches the same conclusions as the preceding literature, finding a significant size-wage premium after ruling out the usual suspects and concluding on the possible importance of unmeasured workforce quality. Abowd, Finer and Kramarz (1999) and Abowd, Kramarz and Margolis (1999) estimate a wage equation that includes person-specific and firm-specific unobserved components using longitudinal data on workers and firms in the state of Washington and France respectively. In the latter study, they decompose the firm-size effect into a size effect due to an unobserved person effect and an unobserved firm effect. Their estimation results show that the firm-size-average person effect explains better the size-wage gap than does the firm-size-average firm effect.

The paper is organized as follows. Section two describes the framework of analysis. In the first part of this section, a statistical model of wage determination with non random assignment of workers into firms of different sizes is presented and the different interpretations of the sizewage structure arising from ability sorting and job screening are discussed. The second part of section two presents the estimation method used to estimate the statistical model. Section three describes the data providing information on the sample selection rules, worker mobility across firm size and an analysis of the size-wage gap in the same spirit as the empirical literature on firm size and wage outcomes. Section four presents the results emphasizing the estimated returns to measured skills and unmeasured ability and section five concludes.

\section{Analytical Framework}

In its attempt to explain the size-wage gap, the empirical literature on the effect of firm size on wages has not considered the possibility that large and small firms may have different wage policies in terms of rewarding workers skills. On the other hand, two main theories of wage determination can justify differences in wage policies by firm size and in particular, differences case. 
in the returns to measured and unmeasured skills based on the following assumptions. On the one hand, ability sorting assumes that skills (measured and unmeasured) are not identically productive across firms of different sizes and in particular, high ability workers have a comparative advantage in large firms. On the other hand, job screening assumes that monitoring costs increase with the size of the firm so that large firms put less weight on unmeasured ability relative to small firms as it is harder to identify. This section summarizes these two approaches in a statistical model of wage determination and present the econometric method used to estimate the returns to ability and evaluate the importance of the ability sorting versus job screening hypothesis in explaining the relationship between firm size and wages.

\subsection{Implications of Ability Sorting and Screening in Wage Policy by Firm Size}

This section presents a statistical model of wage determination which integrates the notions of ability sorting and job screening. The ability sorting argument follows the literature on job assignment and workers comparative advantage first proposed by Roy (1951) and later formalized by Sattinger (1995). ${ }^{8}$ The main assumption in this framework is that different skills (measured and unmeasured) are not equally productive across sectors and in the present context, across firms of different sizes. Utility maximizing workers, in this framework, choose the size of employer for which their abilities are best suited. In particular, high ability workers are better suited in large firms. As a result, the returns to ability are greater in large firms compared to small firms. Job screening and its implications for the analysis of the size-wage relationship was theoretically developed by Garen (1985). The model relies on the assumption that monitoring/evaluation costs increase with firm size. As a result, large firms acquire less

\footnotetext{
${ }^{8}$ See also Neal and Rosen (1998) for more details on selection models and their implications for the earnings distribution.
} 
accurate information about the abilities of their workers, and thus will rely less heavily on their own evaluation of workers than do small firms and more on other indicators of ability such as schooling or experience.

The assumptions common to the two types of approaches are the following: There are two types of firms which differ by size. Firms are indexed by $j=S$ (small), $L$ (large). The only input is labor, given in efficiency units per worker. Workers, indexed by $i=1, \ldots, N$, are characterized by a vector of productive skills, $\left(S K_{i}, \theta_{i}\right)$, where $S K_{i}$ denotes the observed skills of worker $i$ and $\theta_{i}$ represents traits that are unmeasured by the econometrician (these could include innate ability, initiative, ambition, loyalty).

It is assumed that the production technology of firm $j$ exhibits constant returns to scale with respect to labor: ${ }^{9}$

$$
Q_{j}=\sum_{i=1}^{N^{j}} n_{i}^{j}\left(S K_{i}\right)^{\beta_{j}}\left(\theta_{i}\right)^{\lambda_{j}}, j=S, L
$$

where $N^{j}$ is the total number of employees in firm $j$ and $n_{i}^{j}$ is the number of employees in firm $j$ endowed with $\left(S K_{i}, \theta_{i}\right)$. There is one type of output, the price of which is normalized to one. The profit maximizing condition for both types of firms implies the following conditions on the marginal product of workers with skills $\left(S K_{i}, \theta_{i}\right)$ :

$$
w_{i j}=\frac{\partial Q_{j}}{\partial n_{i}^{j}}=\left(S K_{i}\right)^{\beta_{j}}\left(\theta_{i}\right)^{\lambda_{j}}
$$

In the ability sorting model, it is assumed that ability is perfectly observed by firms. ${ }^{10}$

\footnotetext{
${ }^{9}$ It is assumed that firms of different size have different production technologies in terms of the sensitivity to the skills required. The fact that both have constant returns to scale simplifies the analysis. Other assumptions on returns to scale would involve finding the optimal size for both firms which is beyond the scope of this paper.

${ }^{10}$ The model could be generalized to include imperfect information about ability and learning effects in the same spirit as the analysis in Gibbons, Katz, Lemieux and Parent (2001) for the effect of industry and occupational choice on wage outcomes.
} 
Moreover, worker skills, $\left(S K_{i}, \theta_{i}\right)$, are exogenously given so that investment in human capital is ignored. Workers then choose to work in a large (small) firm because they have a comparative advantage in that type of firm.

In the job screening model, Garen (1985) proposes a model explaining the size-wage relationship based on the same idea that firms of different sizes have different wage policies. The assumption used for justifying these differences in compensation policy is not based on differences in skill sensitivity to technology (as it is in the ability model above) but on differences in monitoring costs. It is assumed that large firms rely less heavily on their own evaluation of workers ability than do small firms but instead rely more on more easily observed other indicators of ability such as schooling or experience when making pay decisions. In this approach, the effect of measured and unmeasured skills on wage outcomes will vary by firm size depending upon the degree of accuracy with which workers skills can be evaluated. More precisely, firms face a cost to evaluating workers ability which increases with the size of the firm. This assumption implies that large firms will reward schooling more and ability less and their wage schedule will have a larger intercept. Note that Garen's model goes beyond the simple characterization of the compensation policies of firms of different sizes in that it endogenizes schooling decisions. This part of the model is not detailed in the present paper as it is not directly relevant to the empirical question of the returns to ability in the size-wage relationship.

The idea of different wage policies by firm size can be summarized in the following wage equation:

$$
w_{i j t}=\alpha_{j}+\beta_{j} S K_{i t}+\lambda_{j} \theta_{i}, j=S, L
$$

where $\left(\alpha_{j}, \beta_{j}, \lambda_{j}\right)$ is the vector of rewards to unmeasured and measured skills. The different restrictions on the coefficients resulting from the two types of models can be described in terms of the size-wage premium. The size-wage premium or equivalently, the gain from joining a large 
firm is characterized by:

$$
P_{i t}=\left(\alpha_{L}-\alpha_{S}\right)+\left(\beta_{L}-\beta_{S}\right) S K_{i t}+\left(\lambda_{L}-\lambda_{S}\right) \theta_{i}
$$

According to the ability sorting model, the size-wage premium previously captured in the empirical literature by the differential in the intercepts $\alpha_{j}$ is in fact the result of the differential returns to ability or the difference $\lambda_{L}-\lambda_{S}$. In a one-factor hierarchical ability model with comparative advantage, it is assumed that $\lambda_{L}>\lambda_{S}$ and $\alpha_{L}<\alpha_{S}$. Intuitively, small firms have jobs for which the productivity required and therefore wage paid relies less on individual ability than large firms. Note that in this model, there is no a-priori restrictions on the returns to measured skills and both may be equal unless one assumes a particular correlation between unmeasured and measured skills. One may expect ability to be positively correlated with schooling and experience but other dimensions of ability like ambition or initiatives may not be.

The size-wage structure implied by the job screening hypothesis results in the following restrictions in the parameters: $\beta_{L}>\beta_{S}, \lambda_{L}>\lambda_{S}$ and $\alpha_{L}<\alpha_{S} \cdot{ }^{11}$ A test of the job screening versus ability sorting hypothesis in this context is therefore a test based on the comparison of the $\alpha$ coefficients or the returns to unmeasured skills by firm size. ${ }^{12}$

\subsection{Estimation Method}

This section describes the estimation method used to estimate wage equation (3) described in the previous section. Defining $D_{i j t}$ as a dummy variable indicating whether individual i is in

\footnotetext{
${ }^{11}$ Note that the job screening model can be viewed as a version of a non hierarchical ability or multi-factor ability sorting.

${ }^{12}$ Interpretation of the estimated constant and returns to measured skills are difficult to make since each one depends on the level of ability at which they are estimated which is unknown.
} 
firm of size $\mathrm{J}$ at time $\mathrm{t}$, the empirical version of (3) can be written as follows:

$$
w_{i j t}=\sum_{j=1}^{J} D_{i j t} \alpha_{j}+\sum_{j=1}^{J} D_{i j t} S K_{i t} \beta_{j}+\sum_{j=1}^{J} D_{i j t} \lambda_{j} \theta_{i}+\mu_{i t}
$$

where $\mathrm{J}$ is a discrete variable describing different categories of firm size and $\mu_{i t}$ is a measurement error independent of a worker's choice of firm size. ${ }^{13}$

Estimating equation (5) with OLS would give inconsistent estimates. Indeed, the comparative advantage hypothesis implies that firm size assignment is endogenous, so $\theta_{i}$ is correlated with the firm size dummies. In addition, this term cannot be eliminated by first-differencing (5) because it is interacted with the $D_{i j t}$ terms.

Holtz-Eakin, Newey and Rosen (1988) analyze models in which a fixed effect is interacted with year dummies and show that consistent estimates can be obtained by quasi-differencing the equation of interest and using appropriate instrumental-variable techniques. This technique has been used previously by Lemieux (1998) in the case where the return to a time-invariant unobserved characteristic is different in the union and non-union sector. We also apply this technique to estimate the returns to ability by firm size.

The quasi-differencing method consists of isolating the unmeasured ability term $\theta_{i}$ as follows:

$$
\theta_{i}=\frac{w_{i j t}-\sum_{j}^{J} D_{i j t} \alpha_{j}-\sum_{j}^{J} D_{i j t} S K_{i t} \beta_{j}-\mu_{i t}}{\sum_{j}^{J} D_{i j t} \lambda_{j}}
$$

Innate ability is time-invariant so its period t version is also equal to its lag version. To obtain the quasi-difference, the first lag version of (6) is substituted into equation (5) as follows:

\footnotetext{
${ }^{13}$ In the empirical analysis, we will consider three types of size categories: small, medium and large. The categorization of the firm size variable will be explained in more details in the data section.
} 


$$
\begin{aligned}
w_{i j t}= & \sum_{j=1}^{J} D_{i j t} \alpha_{j}+\sum_{j=1}^{J} D_{i j t} S K_{i t} \beta_{j}+ \\
& \frac{\sum_{j}^{J} D_{i j t} \lambda_{j}}{\sum_{j}^{J} D_{i j t-1} \lambda_{j}} *\left[w_{i j t-1}-\sum_{j=1}^{J} D_{i j t-1} \alpha_{j}+\sum_{j=1}^{J} D_{i j t-1} S K_{i t-1} \beta_{j}\right]+e_{i t}
\end{aligned}
$$

$$
\text { where } \quad e_{i t}=\mu_{i t}+\frac{\sum_{j}^{J} D_{i j t} \lambda_{j}}{\sum_{j}^{J} D_{i j t-1} \lambda_{j}} \mu_{i t-1}
$$

This equation cannot be estimated using non-linear least squares because $w_{i j t-1}$ is correlated with $\mu_{i t-1}$. This problem can be solved by choosing appropriate instruments for $w_{i j t-1}$ in which case consistent estimates will be obtained. The set of instruments, $Z_{i}$, has to satisfy the following condition:

$$
E\left(e_{i t} Z_{i}\right)=0
$$

The objective is then to minimize the following quadratic form:

$$
\min _{\gamma} e(\gamma)^{\prime} Z\left(Z^{\prime} \Omega Z\right)^{-1} Z^{\prime} e(\gamma)
$$

where $Z^{\prime} \Omega Z$ is the covariance matrix of the vector of moments $Z^{\prime} e(\gamma), \Omega$ is the covariance matrix of the error term $e_{i t}$ and $\gamma$ is the vector of parameters. An efficient estimator can be obtained by estimating equation (5) in a first step with $\Omega=I$.

Finally, the unmeasured ability term $\theta_{i t}^{e}$ in the error term of equation (5) is normalized to zero for the parameters to be identified. ${ }^{14}$ This is done by adding the following equation as a constraint on the optimization of (10):

$$
(1 / T N) \sum_{i} \sum_{t} \theta_{i t}=0
$$

where $N$ is the number of individuals, $T$ is the number of periods for each individual and $\theta_{i t}$ satisfies equation (6).

\footnotetext{
${ }^{14} \mathrm{~A}$ proof of the necessity of this constraint is given in Lemieux (1998).
} 
Instruments are chosen using the identification assumption for estimation of panel data equations that imposes strict exogeneity of right-hand side variables. More formally:

$$
E\left(\mu_{i t} / S K_{i 1} \ldots S K_{i T}, D_{i j 1} \ldots D_{i j T}, \theta_{i}\right)=0
$$

The elimination of $\theta_{i}$ resulting from the quasi-differencing corrects the problem of endogeneity in the assignment of workers to firms of different sizes. The equation still needs to be instrumented due to the presence of the lagged wage on the right-hand side which is correlated with $\mu_{i t-1}$. Equation (12) states that conditional on observed innate ability, individual characteristics and firm size assignments each period are uncorrelated with the error term in the wage equation (5). Therefore, this condition provides a set of potentially valid instruments with the property that they are not correlated with the $\mu$ terms in the $e$ term from equation (8). In particular, the history of previous period firm size assignments (interaction terms between $D_{i j t-1}$ and $\left.D_{i j t}\right)$ as well as previous period firm size assignment interacted with skills should help predict wages.

\section{$3 \quad$ Data and Preliminary Analysis}

In this section we describe the data focusing, in particular, on worker mobility across firms of different sizes. We also present an analysis of the size-wage gap in the same spirit as the empirical literature on firm size and wage outcomes. We use data from the Survey of Labour and Income Dynamics (SLID). The SLID data is collected by Statistics Canada in the form of a 6 year panel containing information about individuals. In particular, an extensive set of individual and job characteristics are available for each of the six years of each panel, which runs from 1993 to 1998. We select individuals between 20 and 64 years of age, working for positive wages in sectors other than construction, and for whom we have observations on at least three consecutive years. We limit the sample to those who answered questions about 
wages, education and firm size. These restrictions leave us with a sample of 17,766 observations (worker-year) of which around $24 \%$ are associated with a change in firm size.

Following other work in the area, we categorize firm size as large (more than 1000 employees) medium (between 500 and 999 employees) and small (less than 500 employees). Table 1 shows different firm and worker characteristics by firm size. In general, wages in large and medium firms are about $21 \%$ higher than in small firms. However, workers in large and medium firms have higher levels of education and more experience as well. Additionally, there is evidence in the literature that union coverage may be a factor affecting the size wage gap. Indeed, unionization increases by half in large firms, where it covers $62 \%$ of the workers, relative to small firms, where unionization rate is $42 \%$.

In the analysis hereafter, we consider the distribution of other job characteristics that could be related to wage dispersion across firm size. In particular, we contemplate the possibility that large and small firms make different use of complementary forms of compensation, like receiving a pension plan or commissions and tips. This is in fact the case looking at the descriptive

statistics in table 1, since large (and medium) firms are more likely to offer a pension plan. Workers in large firms are also more likely to obtain commissions. We also consider other work practices, not related to compensation, that may make a job more (less) attractive. These are mainly related to job responsibilities, like whether the worker has the ability to influence budget or staff decisions, if he/she is involved in pay and promotion decisions, or whether he/she supervise others. These, however, do not show a distinct pattern by firm size.

\subsection{Analysis of Firm Size Changes}

To explore whether individuals perceive firm size to be a relevant variable in their choice of job, we take a further look at workers that report a change in firm size. Table 2 presents the transition probabilities of firm size change, together with the average wage levels and rate of 
growth. Overall, $43.5 \%$ of the observations are in small firms, $11.4 \%$ in medium firms and $45.1 \%$ in large firms in period $t$. Interestingly, the percentages of moves out of any categories (small, large or medium) is very similar varying between $3.3 \%$ and $4.6 \%$. In other words, the $24 \%$ of observations reporting changes are evenly distributed across firm size.

In terms of average gains associated with moving, one can see that moves to large firms (either out of medium or small firms) are associated with greater average wages and greater wage growth. Interestingly, moving out of large firms does not necessarily imply a cut in wage growth. This observation is in line with a selection model in which workers move out of "bad" matches and into better matches. Note also that there does not seem to be a monotonic pattern of increase in average wages or wage growth when comparing moves to a larger firm (small to medium, medium to large) in that although moves from medium to large firms are associated with greater gains (in level and growth), moves from small to medium are not. This suggests the presence of asymmetry in the characteristics influencing firm size changers.

Because some of the moves may not reflect a worker move but either misclassification in firm size between two years or the fact that the same firm is expanding or shrinking over time (due to substantial hiring or layoffs), we are interested in analyzing further the relevance of the reported moves. We therefore looked into the factors that may influence the probability of moving to a firm of a different size. To this effect we run a probit estimation on firm size change that includes education, experience, union status, and different forms of past compensation among the main explanatory variables to be used as possible factors correlated with moves. We consider the possibility that moving to a larger firm represents a different type of choice for the workers than moving to a smaller firm and the dependent variable is an indicator for whether the worker moved to a larger firm. ${ }^{15}$

\footnotetext{
${ }^{15}$ Moving to a smaller firm shows similar returns, except that the coefficient for the commission variable is not significant. These results are available from the authors upon request.
} 
The results of the probit analysis are presented in table 3. In general, low levels of education and experience are negatively correlated with the probability of moving to larger firms, whereas unionization is positively correlated. These effects were also apparent in the raw data. The most interesting results come from the variables related to work compensation. In the first column we use past wages (in levels) to measure the main form of compensation, and in the second column we use past wage growth for this purpose. In both columns, the main form of compensation (either past wage or past wage growth) have a (strong) negative influence in the probability of moving to larger firms, suggesting that most moves are related to improved pay opportunities. Other forms of compensation also appear to significantly influence the probability of moving to larger firms. Those that received tips or commissions in the past are less likely to move. This is likely to happen because these forms of compensation are usually linked to the development of a clientele or other firm-specific investments. It is worth noting that these variables are not significant when we analyze the probability of moving to small firms, ${ }^{16}$ which again points to asymmetries in the type of firm size changers.

Overall, the above examination of the data seems to support the idea that observable skills are rewarded differently among large and small firms. There also seems to exist an asymmetry in the moves to large and small firms, in terms of wage compensation. Finally, the results from the probit analysis are intuitive in that movers to larger firms are on average more educated, less experienced and that moves follow from poor pay outcomes at the current firm.

\subsection{The Size-Wage Gap}

In this section we replicate the analysis performed in previous empirical studies analyzing the links between firm size and wages. Empirical studies on the determinants of wage and wage growth have analyzed possible departures from the basic Mincer-type wage equation

\footnotetext{
${ }^{16}$ Results available upon request.
} 
that explains wages as a function of education and a quadratic in experience. Since the wage equation is originally derived from a model of optimal investment in human capital, it does not offer a complete representation of the labor market as it only describes the supply side of the market. Most studies add variables to the wage equation that describe and capture variations in wages related to the demand side of the labor market. In particular, industry, occupation, unionization, establishment and firm size dummies are the main variables employed. This type of analysis allows one to obtain an estimate of the average size-wage gap.

Table 4 presents the results of a cross-sectional OLS estimation of employer-size wage differentials in the spirit of the empirical literature on firm size and wage outcomes. Overall, the results are similar to those reported elsewhere in the literature. Column (I) shows the average size-wage gap in the absence of other firm controls. The coefficient associated with the dummy for a large and a medium firm gives a wage differential of $15 \%$ and $12 \%$ respectively. This is similar to those estimated in Morissette (1993) using the Canadian Labour Market Activity Survey (LMAS) for 1986, which suggests that the magnitude of the gaps has not changed over time. Column (II) shows the results when controls for big establishment, unionized worker, industry, occupation, and public sector workers are added to the wage equation. The size of the coefficients associated with firm size drops substantially to $8 \%$ and $5 \%$ for large and medium firms respectively. Overall, and similarly to others in the literature, we find that employment characteristics, such as a public sector, unionization or big establishment explain a sizeable portion (around 50\%) of the size wage gap. Industry and occupation variables have additional though limited effects.

The literature on firm size suggests that unionization has an important effect in reducing wage dispersion and that pay practices or other firm policies will differ among unionized and non unionized firms. Therefore, this is a factor that should be considered in our analysis. Table A1 in the appendix compares the average wage by education level and firm size between 
unionized and non unionized firms. Note that the average union wage gap is much greater among small firms than among large firms implying different size effects on wages for unionized and non unionized workers. ${ }^{17}$ Given these findings, we perform the same type of OLS analysis concentrating only on the sub-sample of non union firms. The size-wage gap is indeed greater, but only slightly, among large non unionized firms (9\%).

Finally and most importantly, we exploit the temporal dimension of our data set to investigate the potential importance of unmeasured ability by comparing the OLS results with the results of fixed-effect estimations. Column (IV) presents the estimates of the fixed effect regression. Note how the coefficient associated with the large firm dummy variable drops substantially, although remains statistically significant. This indicates that the estimates of the previous regressions (including our estimates on firm size) are very likely to suffer from ability bias. This result is also consistent with the literature. In the next section, the role of ability in the relationship between firm size and wages is investigated in greater detail following the statistical model presented in section 2 .

\section{Results}

In this section we present the results of estimations of wage equation (5) in which firm size is interacted with measured skills and unmeasured ability implying different wage policies for firms of different sizes and workers sorting based on comparative advantage and firms screening. Table 5 summarizes the results. We also assess the robustness of the method by performing tests of the validity and predictive power of the instruments.

\footnotetext{
${ }^{17}$ See Lluis (2002) and Pearce (1990) for more details on this particular point for the Canadian case and American case respectively.
} 


\subsection{Returns to Unmeasured Ability by Firm Size}

In the first column of table 5 , simple OLS are applied to estimate the wage equation assuming unmeasured ability is equally rewarded in all firms. This first empirical model serves as a basis for comparison with the case where both measured and unmeasured skills are differently rewarded across firms of different sizes. Note that we summarized workers characteristics into a skill index to obtain a global measure of skills. ${ }^{18}$ To do so, we estimated a regression of the log wage on education, marital status, sex, nationality, experience and squared experience, industry and occupation type for the entire original sample of workers. We then use the estimated coefficients related to education, marital status, gender, nationality and experience to compute the estimated or predicted log wage based on these characteristics. The resulting skill variable has been normalized to 0. Columns II to VI present the results of GMM estimations of equation (7) based on the quasi-differencing method described in section 2.2. Column II uses the full sample while column III considers younger workers, column IV and V use the samples of non unionized workers in managerial and non managerial positions respectively. The last column corresponds to an analysis check of the identification test we will describe in more details at the end of this section.

The results of the OLS estimation in column I show that the large firm dummy variable or intercept is still significant and that the returns to measured skills by firm size are also significant. On the other hand, a test of equality of these returns to measured skills cannot reject the hypothesis that they are all equal. When unmeasured ability is considered (column II-V), the returns to measured skills as well as the large firm effect are substantially reduced, as was the case in table 4 when comparing the OLS and fixed-effect estimations. This result confirms the importance of unmeasured ability in the relationship between firm size and wages.

\footnotetext{
${ }^{18}$ Given the focus on comparative advantage, this technique provides a way to minimize the number of parameters to be estimated. It is similarly used in Gibbons, Katz, Lemieux, Parent (2002) and Lluis (2002),
} 
It is worth noticing the effect of other wage policy characteristics, such as pension plan availability and commission, whose effects are both substantial and significant in the OLS estimation in column I but drop in magnitude once ability is controlled for (column II-V). Note, however, the significant but small effect of having a pension plan for non unionized workers in columns IV and V, which suggests that pension plan holders are high-wage workers even after controlling for ability. Also interestingly, after controlling for ability, the effect of commissions reduces base pay for younger workers (column III).

The most interesting results of table 5 relates to the returns to unmeasured skills. These returns are significant and more importantly, significantly different from one another according to the tests of equality of the coefficients. They are also consistent across the different subsamples studied (columns II-V) suggesting that the effect is robust to different sub-sample related to workers' age, union status or occupation.

In terms of the differential in returns, it is interesting to note the non monotonic relationship between firm size and the level of the returns previously conjectured in the raw data. The returns to unmeasured ability are the highest in medium size firms (above 500 and below 1000 workers). In other words, unmeasured ability is significantly more rewarded in medium size firms relative to small firms. On the other hand, unmeasured ability is not significantly more rewarded in large firms relative to medium or small firms. The first result is in accordance with an explanation based on ability sorting while the second piece is more consistent with an explanation based on monitoring costs. Overall, it seems that ability sorting dominates for moves from small to medium size firms in that ability is more productive and therefore more rewarded in the latter than the former. On the other hand, when firms become "too large", the monitoring costs hypothesis seems to dominate in that ability is not more rewarded than in small firms. ${ }^{19}$

\footnotetext{
${ }^{19}$ The same analysis has been performed for different categorizations of small, medium and large sizes and the
} 


\subsection{Analysis of Instruments}

To assess the robustness of the preceding results, we analyzed the predictive power of the instruments used. To do so, we performed a F-test for the joint significance of the instruments when the instrumented variable (previous wages) is regressed on the instruments, including all the exogenous variables in the right-hand side of the wage equation. The value of the F-test statistic is 3.96 which is above the critical value at the $95 \%$ confidence level. One can therefore conclude that firm size affiliation between $t-1$ and $t$ as well as interactions between firm size affiliation and skills are good instruments for workers' previous period wage.

In terms of the validity of the instruments used to perform the estimation, the test is rejected for the models represented in columns II to IV and not rejected only in the case of non unionized non managerial workers (column V). Note that as explained in details in Gibbons, Katz, Lemieux and Parent (2002), the non-linearity in the model estimated can make the overidentification test fail either because the instruments are invalid or because the instruments are valid but the model is misspecified. One possible reason for misspecification is the restriction we have imposed that the wage model is a single-index model in that both measured and unmeasured skills are uni-dimensional. Our model, like the one in Gibbons, Katz, Lemieux and Parent (2002), is a multiple sector model for which a single measured skills and ability index may be too restrictive. In addition, in this type of model, there are different identification strategies for estimating the slope and intercept associated with each firm size variables. For example, moves to large firms can be identified both through moves out of medium firms as well as moves out of small firms. Table 2 shows that about $5 \%$ of the observations corresponds to these types of moves in each case which is substantial. We follow Gibbons, Katz, Lemieux and Parent (2002) strategy to estimate the model with only observations on adjacent moves. We perform the analysis on the sample of non unionized 
managerial workers (whose results are shown in column IV) to which we drop observations on non-adjacent moves (small to large firms and vice-versa). One can see that the value of the statistic of the overidentification test decreases by half with a p-value such that the assumption of valid instruments now cannot be rejected.

\section{Conclusion}

In this paper we have re-examined the relationship between firm-size and wages by analyzing differences in the way firms of different sizes evaluate workers' skills and in particular unmeasured ability. Using a non linear instrumental variable estimator, we are able to estimate the differential wage impact of unmeasured ability across firms of different sizes. Our data come from the Survey of Labour and Income Dynamics (SLID) over the years 1996 to 2001. The results can be summarized into three following main points:

A preliminary analysis of the data illustrated some differences in the compensation policies of small, medium and large firms. In particular, large and medium firms are more likely to offer a pension plan and workers in large firms are also more likely to obtain commissions. Also an analysis of the extent of firm size changes shows that $24 \%$ of observations report a move to a firm of a different size. These moves are evenly distributed across firm size in that a similar proportion of moves are reported out of small, medium and large firms. In terms of average gains associated with moving, moves to large firms (either out of medium or small firms) is associated with greater average wage and wage growth. Interestingly, moving out of large firms does not necessarily imply a cut in wage growth. Moreover, there does not seem to be a monotonic pattern of increase in average wages or wage growth when comparing moves to a larger firm (small to medium, medium to large) in that although moves from medium to large firms are associated with greater gains (in level and growth), moves from small to 
medium are not. This suggests the presence of asymmetry in the characteristics influencing firm size changers. Finally, a probit analysis for the determinants of firm size changes shows intuitive correlations between workers and compensation characteristics and moves to larger firms. Indeed, movers to larger firms are on average more educated, less experienced and we also find that moves follow from poor pay outcomes at the current firm.

From the GMM estimation of the statistical wage model, we find significant differences in the returns to unmeasured ability across firm size. In particular, we find that the returns to unmeasured ability are the highest in medium size firms (above 500 but below 1000 workers). In other words, the returns to unmeasured ability are significantly greater in medium size firms relative to small firms but are not significantly greater in large firms relative to medium or small firms. Overall, it seems that ability sorting dominates for moves from small to medium size firms in that ability is more productive and therefore more rewarded in the latter than the former. When firms become "too large", however, the monitoring costs hypothesis seems to dominate in that ability is not more rewarded than in small firms. 


\section{References}

Abowd J. M., Finer H. and Kramarz F. (1999) "Individual and Firm Heterogeneity in Compensation: An Analysis of Matched Longitudinal Employer Employee Data for the State of Washington", in "The Creation and Analysis of Employer-Employee Matched Data" (J. Haltiwanger, J. Lane, J. Spletzer, and K. Troske, Eds), 3-24, North-Holland, Amsterdam.

Abowd J. M., Kramarz F. and Margolis D. (1999) "High Wage Workers and High Wage Firms", Econometrica vol. 67, 251-333

Agell J. (2003) "Why Are Small Firms Different? Managers' Views", Working paper, Stockholm University.

Brown C. and Medoff J. (1989) "The Employer Size-Wage Effect", Journal of Political Economy vol. 97, 1027-1059.

Garen J. (1985) "Worker heterogeneity, Job Screening, and Firm Size", Journal of Political Economy vol. 93, 715-739.

Gibbons, R., Katz, L.F., Lemieux, T. and Parent, D. (2002) "Comparative Advantage, Learning, and Sectoral Wage Determination". NBER Working Paper n.8889.

Idson, T.L. and Feaster, D.J. (1990) "A Selectivity Model of Employer Size-Wage Differentials". Journal of Labor Economics, vol. 8 (1) Part 1. pp.99-122.

Lemieux, T. (1998) "Estimating the Effects of Unions on Wage Inequality in a Panel Data Model with Comparative Advantage and Nonrandom Selection". Journal of Labor Economics, vol 16 (2). pp.261-91.

Lluis, S. (2003) "Wage Structure by Firm Size: Evidence from Canada and the United States", Human Resource Research Institute Working Paper \#02-03, University of Minnesota.

Lluis, S. (2002) "The Role of Comparative Advantage and Learning in Wage Dynamics and 
Intra-firm Mobility: Evidence from Germany, Human Resource Research Institute Working Paper \#01-03, University of Minnesota.

Hu, L. (2003) "The Hiring Decisions and Compensation Structures of Large Firms", Industrial and Labor Relations Review, vol 56 (4). pp.663-81.

Morissette, R., (1993) "Canadian Jobs and Firm Size: Do Smaller Firms Pay Less?", The Canadian Journal of Economics, vol.26 (1) pp.159-74.

Neal, D. and Rosen, S. (2000) "Theories of the Distribution of Labor Earnings" in Handbook of Income Distribution vol. 1 Ed. Elsevier

Oi, W. (1983) "Heterogenous Firms and the Organization of Production", Economic Inquiry, vol 21, pp. 147-69

Oi, W. and Idson, T (1999) "Firm Size and Wages" in Handbook of Labor Economics, vol.3B. Ed. Elsevier

Pearce, J. E. (1990) "Tenure, Unions, and the Relationship between Size and Wages", Journal of Labor Economics, vol 8, pp. 251-69.

Roy, A.D (1951) "Some Thoughts on the Distribution of Earnings". Oxford Economic Papers (New SEries) vol. 3, pp.135-46.

Sattinger, M. (1993) "Assignment Models of the Distribution of Earnings", Journal of Economic Literature vol.31 (2). pp.830-880.

Shouyong Shi (2003) "Product Market Differentiation and the Size-Wage Differential". Forthcoming International Economic Review.

Troske, K. (1999) "Evidence on the Employer Size-Wage Premium from Worker-Establishment Matched Data", The Review of Economics and Statistics, vol 81, pp. 15-26.

Winter-Ebmer, R. and Zweimuller, J. (1999) "Firm Size and Wages", The American 
Economic Review, vol 89, pp. 90-93. 
Table 1. Average Sample Characteristics

\begin{tabular}{|lcccc|}
\hline & All & Small Firm & $\begin{array}{c}\text { Medium } \\
\text { Firm }\end{array}$ & Large Firm \\
\hline Hourly Wage & 18.26 & 16.36 & 19.04 & 19.90 \\
Years of Experience & 18.66 & 17.89 & 19.21 & 19.25 \\
Manager & 0.20 & 0.20 & 0.18 & 0.21 \\
Union & 0.54 & 0.42 & 0.66 & 0.62 \\
Public & 0.38 & 0.30 & 0.49 & 0.43 \\
Female & 0.47 & 0.53 & 0.46 & 0.42 \\
High School & 0.27 & 0.25 & 0.23 & 0.30 \\
Post Secondary & 0.42 & 0.43 & 0.42 & 0.40 \\
University & 0.17 & 0.15 & 0.22 & 0.17 \\
Big Establishment & 0.74 & 0.60 & 0.83 & 0.86 \\
Work Practices & & & & \\
Budget/Staff & 0.18 & 0.18 & 0.16 & 0.19 \\
Pay / Promotions & 0.12 & 0.13 & 0.11 & 0.13 \\
Supervise Others & 0.29 & 0.28 & 0.27 & 0.30 \\
Commission & 0.23 & 0.20 & 0.22 & 0.26 \\
Pension Plan & 0.72 & 0.54 & 0.83 & 0.88 \\
& & & & \\
\hline Observations & 17,696 & 7,690 & 2,026 & 7,980 \\
\hline * Large firms have more than 1000 employees. Medium Firms have between 500 and \\
999 employees. Large establishments have more than 20 employees. & \\
\hline & & & & \\
\hline
\end{tabular}


Table 2. Transition Probabilities of Wage Practices

\begin{tabular}{|c|c|c|c|c|}
\hline \multirow[b]{2}{*}{ Firm Size (t-1) } & \multicolumn{4}{|c|}{ Firm Size (t) } \\
\hline & Small & Medium & Large & Total \\
\hline Small (\%) & 35.51 & 3.46 & 4.83 & 43.80 \\
\hline Wage & 16.86 & 19.69 & 19.29 & 17.37 \\
\hline Wage growth \% & 2.81 & 2.77 & 3.18 & 2.85 \\
\hline Commission $\%$ & 18.75 & 20.15 & 18.63 & 19.64 \\
\hline Pension Plan \% & 48.30 & 80.81 & 82.72 & 54.95 \\
\hline Medium (\%) & 3.30 & 4.03 & 4.16 & 11.49 \\
\hline Wage & 18.95 & 19.85 & 19.96 & 19.63 \\
\hline Wage growth \% & 2.24 & 2.28 & 4.07 & 2.98 \\
\hline Commission \% & 18.12 & 24.59 & 18.60 & 20.68 \\
\hline Pension Plan \% & 74.46 & 80.97 & 82.08 & 79.47 \\
\hline Large (\%) & 4.65 & 3.96 & 36.10 & 44.71 \\
\hline Wage & 19.70 & 20.50 & 20.94 & 20.77 \\
\hline Wage growth \% & 2.38 & 3.20 & 2.95 & 2.91 \\
\hline Commission $\%$ & 13.90 & 19.36 & 27.47 & 25.32 \\
\hline Pension Plan \% & 81.61 & 85.19 & 88.12 & 87.17 \\
\hline Total & 43.46 & 11.45 & 45.09 & 100 \\
\hline Wage & 17.37 & 20.03 & 20.67 & 19.21 \\
\hline Wage growth \% & 2.71 & 2.77 & 3.09 & 2.98 \\
\hline Commission $\%$ & 18.90 & 21.28 & 25.81 & 22.43 \\
\hline Pension Plan \% & 54.37 & 82.44 & 87.00 & 72.73 \\
\hline
\end{tabular}


Table 3. Probit Estimates of Moving to Larger Firms

\begin{tabular}{|c|c|c|}
\hline & Logit (I) & Logit (II) \\
\hline \multirow[t]{2}{*}{ High School } & -0.100 & -0.220 \\
\hline & $(0.1401)$ & $(0.1715)$ \\
\hline \multirow[t]{2}{*}{ Post Secondary } & 0.150 & 0.089 \\
\hline & $(0.1281)$ & $(0.1579)$ \\
\hline \multirow[t]{2}{*}{ University } & 0.315 & 0.189 \\
\hline & $(0.1651)$ & $(0.1912)$ \\
\hline \multirow[t]{2}{*}{ Experience } & -0.011 & -0.005 \\
\hline & $(0.0222)$ & $(0.0282)$ \\
\hline \multirow[t]{2}{*}{$\operatorname{Exp2}(100)$} & 0.012 & 0.002 \\
\hline & $(0.0519)$ & $(0.0632)$ \\
\hline \multirow[t]{2}{*}{ Union } & 0.342 & 0.161 \\
\hline & $(0.1041)$ & $(0.1282)$ \\
\hline Wage (t-1) & $\begin{array}{c}-0.326 \\
(0.1478)\end{array}$ & -- \\
\hline \multirow[t]{2}{*}{ Wage Growth $(\mathrm{t}-1)$} & -- & -0.441 \\
\hline & & $(0.2886)$ \\
\hline \multirow[t]{2}{*}{ Commission (t-1) } & -0.388 & -0.526 \\
\hline & $(0.1168)$ & $(0.1479)$ \\
\hline \multirow[t]{2}{*}{ Pension (t-1) } & 0.597 & 0.557 \\
\hline & $(0.1221)$ & $(0.1524)$ \\
\hline \multirow[t]{2}{*}{ Influence Pay (t-1) } & 0.019 & 0.041 \\
\hline & $(0.1584)$ & $(0.1957)$ \\
\hline Observations & 8,894 & 5,882 \\
\hline $\begin{array}{l}\text { Note: The depende } \\
\text { include controls for } \\
\text { that also control for }\end{array}$ & $\begin{array}{l}\text { cator for } m \\
\text { and gend } \\
\text { tion show }\end{array}$ & $\begin{array}{l}\text { All regressions } \\
\text { ions (not shown here) }\end{array}$ \\
\hline
\end{tabular}


Table 4. The Size-Wage Gap

\begin{tabular}{|c|c|c|c|c|}
\hline & (I) & (II) & $\begin{array}{c}\text { (III) } \\
\text { No Union }\end{array}$ & $\begin{array}{c}(\mathrm{IV}) \\
\text { Fixed Effects }\end{array}$ \\
\hline \multirow[t]{2}{*}{ High School } & 0.127 & 0.106 & 0.114 & -0.016 \\
\hline & $(0.0103)$ & $(0.0103)$ & $(0.0165)$ & $(0.0315)$ \\
\hline \multirow[t]{2}{*}{ Post Secondary } & 0.269 & 0.225 & 0.233 & 0.016 \\
\hline & $(0.0094)$ & $(0.0094)$ & $(0.0152)$ & $(0.0321)$ \\
\hline \multirow[t]{2}{*}{ University } & 0.557 & 0.456 & 0.460 & 0.080 \\
\hline & $(0.0117)$ & $(0.0126)$ & $(0.0217)$ & $(0.0595)$ \\
\hline \multirow[t]{2}{*}{ Experience } & 0.025 & 0.021 & 0.029 & 0.040 \\
\hline & 0.0017 & 0.0017 & 0.0025 & 0.0020 \\
\hline \multirow[t]{2}{*}{$\operatorname{Exp2}(/ 100)$} & -0.034 & -0.030 & -0.040 & -0.03 \\
\hline & 0.0041 & 0.0041 & 0.0063 & 0.0048 \\
\hline \multirow[t]{2}{*}{ Large Firm } & 0.141 & 0.076 & 0.087 & 0.015 \\
\hline & 0.0073 & 0.0075 & 0.0122 & 0.0047 \\
\hline \multirow[t]{2}{*}{ Medium Firm } & 0.109 & 0.051 & 0.050 & 0.009 \\
\hline & 0.0108 & 0.0106 & 0.0179 & 0.0052 \\
\hline \multirow[t]{2}{*}{ Big Establishment } & -- & 0.095 & 0.108 & -0.000 \\
\hline & & 0.0089 & 0.0126 & 0.0055 \\
\hline \multirow[t]{2}{*}{ Public } & -- & 0.169 & 0.199 & -0.005 \\
\hline & & 0.0116 & 0.0221 & 0.0199 \\
\hline \multirow[t]{2}{*}{ Union } & & 0.084 & -- & 0.012 \\
\hline & & 0.0084 & & 0.0068 \\
\hline Ind./ Occ. & -- & Yes & Yes & Yes \\
\hline Observations & 17,696 & 17,696 & 8,200 & 17,696 \\
\hline R-squared/within & 0.401 & 0.474 & 0.534 & 0.085 \\
\hline
\end{tabular}

NOTE: All regressions include controls for marital status, gender, immigrant, visible minority, language, province, cma and year 
Table 5. Returns to Unmeasured Skills by Firm Size

\begin{tabular}{|c|c|c|c|c|c|c|}
\hline & $\begin{array}{l}\text { I OLS } \\
\text { All Wkrs }\end{array}$ & $\begin{array}{l}\text { II GMM } \\
\text { All Wkrs }\end{array}$ & $\begin{array}{l}\text { III GMM } \\
\text { Age }<=45\end{array}$ & $\begin{array}{l}\text { IV GMM } \\
\text { Managerial } \\
\text { Wkrs } \\
\text { Non unionized } \\
\end{array}$ & $\begin{array}{l}\text { V GMM } \\
\text { Non Managerial } \\
\text { Wkrs } \\
\text { Non unionized } \\
\end{array}$ & $\begin{array}{l}\text { VI GMM } \\
\text { Sample IV } \\
\text { but Adjacent } \\
\text { Moves only } \\
\end{array}$ \\
\hline Medium Firm & $\begin{array}{l}0.000 \\
(0.008)\end{array}$ & $\begin{array}{l}0.003 \\
(0.017)\end{array}$ & $\begin{array}{l}-0.003 \\
(0.023)\end{array}$ & $\begin{array}{l}0.045 \\
(0.045)\end{array}$ & $\begin{array}{l}-0.023 \\
(0.025)\end{array}$ & $\begin{array}{l}0.074 \\
(0.052\end{array}$ \\
\hline Large Firm & $\begin{array}{l}0.041^{* * *} \\
(0.005) \\
\end{array}$ & $\begin{array}{l}0.014^{*} \\
(0.008)\end{array}$ & $\begin{array}{l}0.012 \\
(0.013)\end{array}$ & $\begin{array}{l}-0.000 \\
(0.021)\end{array}$ & $\begin{array}{l}0.029^{* *} \\
(0.014) \\
\end{array}$ & $\begin{array}{c}0.054 \\
(0.050)\end{array}$ \\
\hline Commission & $\begin{array}{l}0.023^{* * *} \\
(0.005)\end{array}$ & $\begin{array}{l}-0.009 \\
(0.004)\end{array}$ & $\begin{array}{l}-0.015^{* * *} \\
(0.005)\end{array}$ & $\begin{array}{l}-0.003 \\
(0.009)\end{array}$ & $\begin{array}{l}-0.007 \\
(0.007)\end{array}$ & $\begin{array}{l}-0.005 \\
(0.009)\end{array}$ \\
\hline Pension Plan & $\begin{array}{l}0.157^{* * *} \\
(0.157) \\
\end{array}$ & $\begin{array}{l}0.004 \\
(0.006) \\
\end{array}$ & $\begin{array}{l}0.001 \\
(0.007) \\
\end{array}$ & $\begin{array}{l}0.022^{*} \\
(0.013) \\
\end{array}$ & $\begin{array}{l}0.021^{* * *} \\
(0.008) \\
\end{array}$ & $\begin{array}{l}0.018 \\
(0.013) \\
\end{array}$ \\
\hline \multicolumn{7}{|l|}{$\begin{array}{l}\text { Returns to Measured } \\
\text { Skills }\end{array}$} \\
\hline Small Firm & $\begin{array}{l}0.359^{* * *} \\
(0.008)\end{array}$ & $\begin{array}{l}0.161^{* * *} \\
(0.048)\end{array}$ & $\begin{array}{l}0.166^{* * *} \\
(0.043)\end{array}$ & $\begin{array}{l}0.153^{* * *} \\
(0.061)\end{array}$ & $\begin{array}{l}0.181^{* * *} \\
(0.073)\end{array}$ & $\begin{array}{l}0.189^{* * *} \\
(0.064)\end{array}$ \\
\hline Medium Firm & $\begin{array}{l}0.335^{* * *} \\
(0.016)\end{array}$ & $\begin{array}{l}0.002 \\
(0.067)\end{array}$ & $\begin{array}{l}0.097 \\
(0.079)\end{array}$ & $\begin{array}{l}0.014 \\
(0.109)\end{array}$ & $\begin{array}{l}0.119 \\
(0.138)\end{array}$ & $\begin{array}{l}0.049 \\
(0.114)\end{array}$ \\
\hline Large Firm & $\begin{array}{l}0.363^{* * *} \\
(0.007)\end{array}$ & $\begin{array}{l}0.092^{*} \\
(0.051)\end{array}$ & $\begin{array}{l}0.093^{*} \\
(0.058)\end{array}$ & $\begin{array}{l}0.210^{* * *} \\
(0.069)\end{array}$ & $\begin{array}{l}0.186^{* * *} \\
(0.071)\end{array}$ & $\begin{array}{l}0.137^{* * *} \\
(0.110)\end{array}$ \\
\hline $\begin{array}{l}\text { Test for Equality of } \\
\text { Returns }\end{array}$ & & & & & & \\
\hline $\begin{array}{c}\mathrm{S}=\mathrm{M} \\
\text { (p-value) } \\
\mathrm{M}=\mathrm{L} \\
\text { (p-value) }\end{array}$ & $\begin{array}{l}1.73 \\
(0.18) \\
2.29 \\
(0.13) \\
\end{array}$ & $\begin{array}{l}3.46 \\
(0.06) \\
0.90 \\
(0.34) \\
\end{array}$ & $\begin{array}{l}0.46 \\
(0.49) \\
0.00 \\
(0.97) \\
\end{array}$ & $\begin{array}{l}1.18 \\
(0.28) \\
1.92 \\
(0.17) \\
\end{array}$ & $\begin{array}{l}0.10 \\
(0.75) \\
0.12 \\
(0.72) \\
\end{array}$ & $\begin{array}{l}1.09 \\
(0.29) \\
0.26 \\
(0.60) \\
\end{array}$ \\
\hline \multicolumn{7}{|l|}{$\begin{array}{l}\text { Returns to } \\
\text { Unmeasured Skills }\end{array}$} \\
\hline Small Firm & & 1 & 1 & 1 & 1 & 1 \\
\hline Medium Firm & & $\begin{array}{l}1.473^{* * *} \\
(0.218)\end{array}$ & $\begin{array}{l}1.585^{* * *} \\
(0.228)\end{array}$ & $\begin{array}{l}1.533^{* * *} \\
(0.264)\end{array}$ & $\begin{array}{l}1.329 * * * \\
(0.255)\end{array}$ & $\begin{array}{l}1.523^{* * *} \\
(0.303)\end{array}$ \\
\hline Large Firm & & $\begin{array}{l}1.164^{* * *} \\
(0.205) \\
\end{array}$ & $\begin{array}{l}1.263^{* * *} \\
(0.220)\end{array}$ & $\begin{array}{l}0.922^{* * *} \\
(0.204)\end{array}$ & $\begin{array}{l}0.915^{* * *} \\
(0.161)\end{array}$ & $\begin{array}{l}0.966^{* * *} \\
(0.373)\end{array}$ \\
\hline \multicolumn{7}{|l|}{$\begin{array}{l}\text { Tests for Equality of } \\
\text { Returns }\end{array}$} \\
\hline $\begin{array}{c}S=M \\
\text { (p-value) }\end{array}$ & & $\begin{array}{l}4.68 \\
(0.03)\end{array}$ & $\begin{array}{l}6.58 \\
(0.01)\end{array}$ & $\begin{array}{l}4.07 \\
(0.00)\end{array}$ & $\begin{array}{l}1.66 \\
(0.19)\end{array}$ & $\begin{array}{l}2.98 \\
(0.08)\end{array}$ \\
\hline $\begin{array}{c}\mathrm{M}=\mathrm{L} \\
\text { (p-value) }\end{array}$ & & $\begin{array}{l}3.61 \\
(0.05)\end{array}$ & $\begin{array}{l}2.71 \\
(0.09)\end{array}$ & $\begin{array}{l}8.65 \\
(0.00)\end{array}$ & $\begin{array}{l}4.39 \\
(0.03)\end{array}$ & $\begin{array}{l}5.20 \\
(0.02)\end{array}$ \\
\hline $\begin{array}{l}\text { Overidentification } \\
\text { Test } \\
\text { (p-value) }\end{array}$ & & $\begin{array}{l}66.00 \\
(0.00) \\
\end{array}$ & 56.71 & 62.10 & 30.76 & 30.10 \\
\hline $\mathbf{N}$ & 17696 & 17696 & 12030 & 3288 & 4912 & 3016 \\
\hline
\end{tabular}

NOTE: All regressions include controls for marital status, gender, immigrant, visible minority, language, province, cma and year. The tests for equality of returns are $\chi^{2}$ tests. 
Table A1. Average Wage by Education, Firm Size and Union Status

\begin{tabular}{|c|c|c|c|c|c|c|c|c|c|c|c|}
\hline & \multicolumn{4}{|c|}{ Non Union } & \multicolumn{4}{|c|}{ Union } & \multicolumn{3}{|c|}{ TOTAL } \\
\hline & Small & Medium & Large & Total & Small & Medium & Large & Total & Small & Medium & Large \\
\hline Less than HS & 11.75 & 13.01 & 13.65 & 12.26 & 14.37 & 15.15 & 17.91 & 16.31 & 12.73 & 14.4 & 16.79 \\
\hline High School & 13.47 & 16.54 & 17.05 & 15.16 & 16.25 & 16.70 & 19.11 & 18.04 & 14.38 & 16.63 & 18.24 \\
\hline Post Secondary & 15.28 & 17.43 & 18.94 & 16.75 & 18.26 & 19.17 & 20.05 & 19.30 & 16.53 & 18.59 & 19.64 \\
\hline University & 22.31 & 27.63 & 27.26 & 25.27 & 24.07 & 24.37 & 24.62 & 24.37 & 23.36 & 25.32 & 25.67 \\
\hline Average & 14.83 & 18.45 & 19.36 & 16.80 & 18.50 & 19.35 & 20.23 & 19.53 & 16.36 & 19.04 & 19.90 \\
\hline Observations & 4,494 & 698 & 3,008 & 8,200 & 3,196 & 1,328 & 4,972 & 9,496 & 7,690 & 2,026 & 7,980 \\
\hline
\end{tabular}


